\title{
Developing a Constructivist Model for Effective Physics Learning
}

\author{
Aina, Jacob Kola \\ Physics Education Department, College of Education (Technical) \\ Lafiagi Kwara State, Nigeria
}

\begin{abstract}
The paper considered developing a constructivist model for effective physics teaching. The model is imperative because of the increasing difficulty in learning physics and the resulting poor academic performance in the subject. The paper reviewed two types of constructivism which are the social and cognitive constructivism. Highlights of correlations between the constructivist learning and the authentic learning were revealed. To applying the model to physics learning, it was argued that constructivist teachers should give serious attention to the prior knowledge of the students. This will determine the mode of teacher instruction. The teacher content knowledge and pedagogical knowledge are central to excellent teaching. The paper concludes that physics teacher should promote student interactions and respect student ideas: being the kernel of the constructivist learning.
\end{abstract}

Keywords: constructivism, constructivist teacher, social interaction, conception

\section{INTRODUCTION}

The learning problem in physics is increasing as revealed by the students' poor academic performance in the subject (Folashade and Akinbobola, 2009; Eraikhueme and Ogumogu, 2014; Mekonnen, 2014) in all level of education. Besides academic performance, research studies show that physics students find it difficult to transfer theory to practice. In other words, most physics students cannot use what is learned in the classroom to solve the problem in a new situation (Watkins and Mazur, 2013). Studies revealed that physics students came into learning situation with preconceptions about physics concepts, principles, laws, and theories. Many of these conceptions have their background in culture, religion, and superstitions (Eraikhueme and Ogumogu, 2014) which have been impacting students learning in physics. Many physics educators and teachers often ignored this issue and therefore could not produce students with agood grade in physics. Learning is crucial in schooling and should start from knowledge the students brought into the learning situation.

Constructivism emphasizes the importance of the knowledge, beliefs, and skills that an individual brings to the experience of learning (Garbett, 2011, p.37). Constructivist theories have their roots in Piaget and focus on the active character of the learner, interacting with the environment either singly or with others (Packer \& Goicoechea, 2000). Constructivism believes that learners play an active role in constructing meaning by themselves (Cornu and Peters, 2005).Constructivism posits that people construct their understanding and knowledge of the world through experiencing things and reflecting on those experiences (Thirteen Ed Online, 2004).Constructivism as a learning theory believes that learning is an active process; knowledge is constructed from experience and a personal interpretation of the world (Christie 2005). Constructivism benefits students in many ways as asserted by Christie that it help students pursue personal interests and purposes; use and develop learners' abilities; build on the learners' prior knowledge and experiences and develop life-long learning. 
There is both social and cognitive constructivism within the contexts of education. The social constructivism deals with the knowledge students constructed through the social interaction. The argument of cognitive constructivism is that knowledge is not directly transmittable from person to person, but rather constructed or discovered individually. Learner-centred and discovery-oriented learning processes are the primary emphases of cognitive constructivists. According to Liu and Matthews (2005), in the process, social environment, and social interaction work merely as a stimulus for individual cognitive conflict (p.388).

\section{Social and Cognitive Constructivism}

Social constructivism derived from the work of Vygotsky emphasizes the important role of social environment in learning. Social constructivist believes student learned from his or her interaction with his or her immediate environment. In this view, learning is considered to be a situation-specific and contextbound activity (Eggen and Kauchak, 1999,).

Social constructivism was developed by Vygotsky who argued that learning is a social and collaborative activity where people create meaning through their interactions with one another (Schreiber and Valle, 2013). Students created ideas through interaction with the teacher and other students.

Interaction is very crucial to students' learning. Educause Learning Initiative (2005) argued that successful learning closely link to interaction. Learning is a process of interaction through which the learners develops their understanding by assembling facts, experiences, and practices.

For Powell and Kalina (2010), collaboration and social interaction are incorporated in social constructivism. This theory believes in the social interaction of students in the classroom along with the critical thinking process. Creating a deeper understanding of learning requires cooperative learning. These authors contended that social learning is a part of creating a social constructivist classroom. The theory believes that students have plenty to offer one another by not only working one-on-one with the teacher but also with other students.

Cognitive constructivism, credited to Piaget where learners have a way of viewing learning in their personal way. Students interpret what they hear in the light of their own knowledge and experience. Cognitive constructivism approaches the construction of knowledge from the perspective of the individual. It, therefore, implies that each student learns new information when he/ she connect the prior experience with the new situation on a personal basis.

A state of imbalance or disequilibrium is created when a new situation emerges that challenges what a learner already knew or the way he/she is thinking (Amineh and Asl, 2015). It is a personal cognitive process that may either lead to the assimilation of the new information or its rejection.

According to Kim (2001), individual create meaning through their interactions with each other and with the environment where they live. The author argued that meaningful learning could only take place when students are engaged in social activities. Andrews (2012), social constructivism is concerned with the nature of knowledge and how it is created. Social constructivism believes that both the context which learning occurs and the social contexts that the learners bring to the classroom is crucial (Kim, 2001). Social constructivism has a perspective that focuses on the relationship between people and their environment (Kim, 2001). The author believed students learned with their mind and at the same time interacts with the environment as learning is going on, it is, therefore, difficult to separate learning from the environment. Bredo (1994) noted that if the environment and social relationships among groups of students change, apparently the tasks of each student also change. Thus, Kim said learning should not and cannot take place in isolation from the environment. 
Powell and Kalina (2011), an active classroom, where teachers and students are communicating optimally, is dependent on using constructivist strategies, tools, and practices. Students' construction of knowledge (Kirschner, Sweller, and Clark, 2006) by themselves is central to the constructivism: this is done through active participation in the learning task. Supporting this is Prawat and Floden (1994) that constructivism is based on the idea that knowledge is actively constructed by the students.

Learning is a social activity. Learning is intimately associated with connection with other human beings, teachers, peers (Hein, 1991). Biggs (1999) argues that constructivism holds the belief that meaning should not be imposed or transmitted by direct instruction, but allows the students generate information created by learning activities. Kim (2005) summarizes what is expected of a teacher in a constructivist classroom very similar to the authentic learning as follow.

$>$ Encourage student's leadership, cooperation, seeking information, and the presentation of the ideas,

$>$ modify their instructional strategies in the process of teaching based on students; thought, experience and or interests

$>$ use printed materials as well as experts to get more information

$>$ encourage free discussions by way of new ideas inviting student

$>$ questions and answers

$>$ help students to test their ideas

$>$ invite students' ideas, before the student, is presented with the ideas and instructional materials

$>$ encourage students to challenge the concepts and ideas of others

$>$ use cooperative teaching strategies through student interactions and respect, sharing ideas and learning tasks

$>$ encourage students to respect and use other people's ideas (p.10).
Kroll (2004) suggests that constructivist classroom students should be able to construct for themselves an articulated vision of learning, teaching, development, and knowledge. According to Huang (2002), constructivism emphasizes the development of learners' ability in solving real-life problems.

The teacher only acts as a facilitator but not the provider of the knowledge in the constructivist classroom. This underscores the similarity between the constructivist class and the authentic learning class. The basis of the authentic learning has been to give the students enough opportunity to control their learning while the teacher plays coaching and scaffolding role.

In an authentic learning environment, teachers' knowledge and textbooks are severely discouraged to allow students direct their learning. The learning task is ill-defined. Brandon and All emphasized that constructivism believes that instead of using the teacher's knowledge and textbooks for solving problems, the student invents solutions and constructs knowledge in the learning process. The students in an authentic learning are guided to learn in a way to apply their learning to everyday life (Aina, 2017). The table below shows correlations between constructivism and an authentic learning (Herrington and Kelvin, 2007; Johnston, 2005; Brooks and Brooks, 1993). 
Table 1

Correlation between the Constructivism and the Authentic Learning

Constructivism

Student autonomy: students attain their intellectual identity. Students draft questions by themselves, analyze it, answer it and take responsibility for their learning. The student plays a central role in mediating and controlling learning. An exploration is a favoured approach to encourage students to seek knowledge independently and to manage the pursuit of their goals.

Higher-level thinking: students' are encouraged to summarize concepts through analyzing, predicting, justifying and defending ideas. Problem-solving, higher-order thinking skills and deep understanding are emphasized.

Dialogue: students change ideas through discussion with the teacher and the peers. Student builds personal knowledge based on the understanding. When students feel comfortable to express their ideas, meaningful classroom dialogue begins.

Student's activities: students have the opportunities to test their hypotheses through group discussions and solid experience. The construction of knowledge takes place in individual contexts and through social negotiation, collaboration, and experience.

Students use different resources: involves students in real-world possibilities, generate abstractions binding phenomenon together. Multiple perspectives and representations of concepts and content are presented and encouraged.

Teachers serve in the role of guides, monitors, coaches, tutors and facilitators. Scaffolding is facilitated to help students perform just beyond the limits of their ability.

The learning situations, environments, skills, content and tasks are relevant, realistic, authentic and represent the inherent complexities of the 'real world.'
Authentic Learning

Students connect with others who share their passions and ideas. Students have personal control over what and how they learned. Students learned by themselves.

Students exercise higher levels of thinking. Students provide answers to questions through the thinking skill and inquiry. It engages learners in the opportunities of solving complex real-world problems and finding out solutions. Students articulate their understanding by defending it among the group members.

Students participate in the discussion. There is no passive learner. No rigid idea but students build knowledge as they all participates in meaningful group discussion.

Student collaborates to solve problems. Collaboration provides joint problem solving and social support. Worked in team or pairs, not individuals; task-focused groups not individual.

It allows different perspectives from different points of view; not just a single perspective- such as a textbook. Provides the learner with the opportunity to investigate multiple ideas, roles, and perspectives.

The teacher provides for coaching at critical times, and scaffolding of support, where the teacher provides the skills, strategies, and links that the students are unable to provide to complete the task.

This is a situation that reflects the way the knowledge will be used in real-life. This is an authentic learning environment. 


\section{Conceptual Framework}

The student learning is the crux of the constructivism theory. In other words, the student is at the center of the constructivist model: every other thing revolves around the students. The teacher comes to the class because of the students; whatever instructional method to be employed the students are considered first. Therefore, the prior student knowledge serves as the springboard on which the learning process starts. Students link any new information with the previous knowledge either individually or while interacting with a peer or the teacher.
Thus, both the construction of knowledge by social interactions and the individual is to enhance students' learning. The teacher instructs based on the students' interactions (contextual learning) and students' preconception. A clear and good instruction that enhance student's learning depends on the teacher's content and the pedagogical knowledge. Therefore, through this framework, a model in the figure below is developed for effective students' learning.

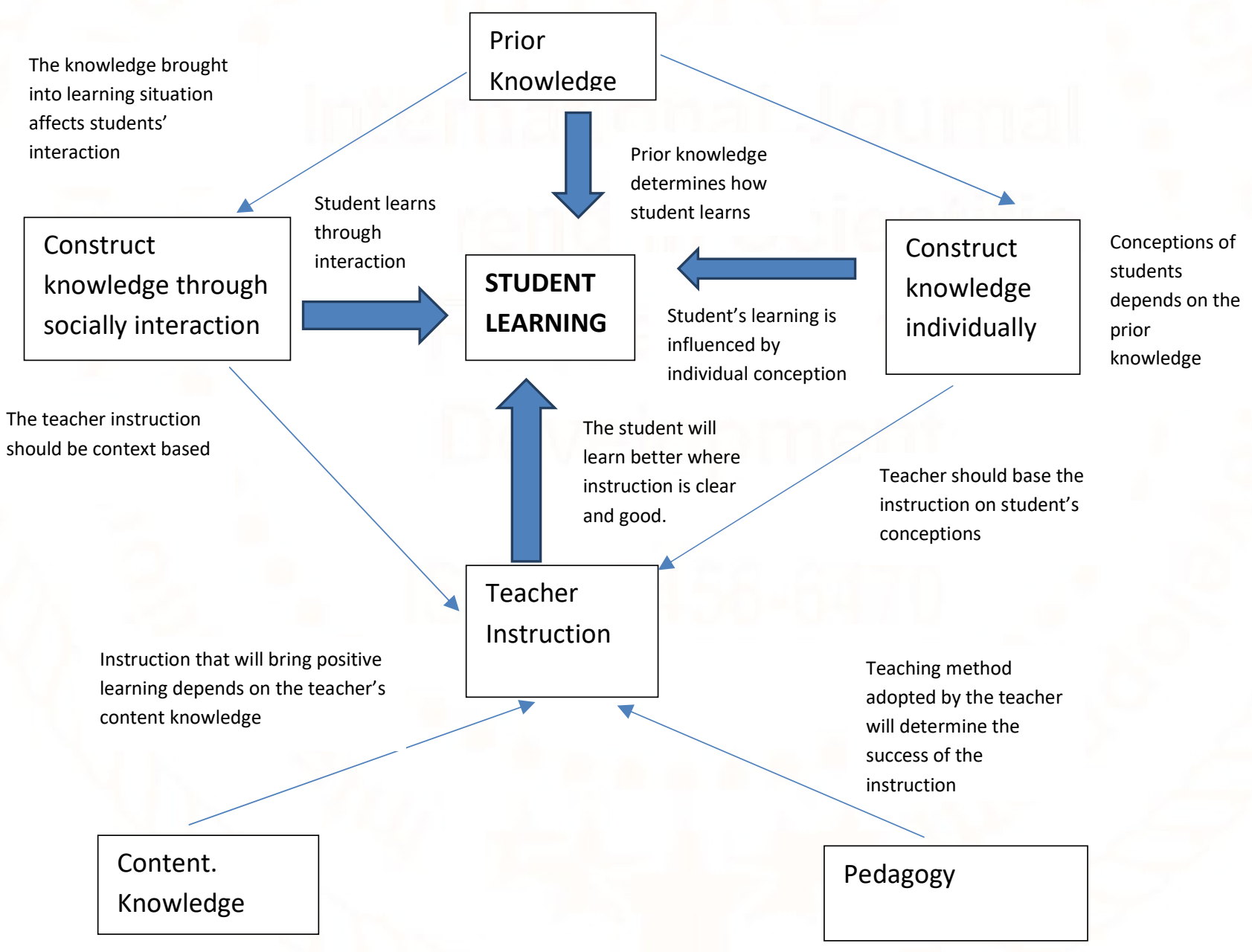

Figure 1. Posited Constructivist Model 


\section{Applying Constructivist Model to Physics} Learning

The teacher is expected to make students actively involved in the classroom because active learning stimulates inquiry (McCarthy and Anderson, 2000). However, research studies show that the traditional lecture approach still dominates teaching in schools (Deslauriers, Schelew, and Wieman, 2011). Scholars argued that the present way of teaching physics must be changed because it is dull and uninteresting to young students. For Rodrigues and Oliveira (2008), this method does not meet the actual requirements of society and the new trends of physics curricula.

Crouch, Watkins, Fagen and Mazur (2007) affirmed that traditionally taught courses do little to improve students' understanding of the central concepts of physics. Research shows that commonly used teaching methods such as the traditional lecture method do not help the students acquire sufficient functional understanding of physics(Bernhard, Lindwall, Engkvist, and Zhu, 2007). Rote learning is a common experience of the students in physics; they learned to forget because it is by memorization (Fagen and Mazur, 2003). According to Aina and Langenhoven (2015), physics students are unable to apply classroom experience outside the classroom because they learned by memorization.

The effective learning of physics starts with the teacher knowing the prior knowledge of the students. The physics teacher should know what experience the students had on the concept to be discussed. This knowledge will determine the teacher approach to the instruction. One of the reasons for mass failure in physics is because many teachers come to class to start lecturing without considering students' entering knowledge. Most students cannot link the new information given by the teacher with what they had preconceived. Thus, confusion sets in and to resolve the confusion many students result into memorization of the new information. Memorization is not a good way of authentic learning.
Students will learn effectively in physics if the teacher gives the students maximum chance for social interaction. Many of these students had something in mind before coming to the class: they were not blank slates (tabula rasa) but came in with knowledge. During the interaction, the students would be able to resolve many of the preconceived wrong or right knowledge within themselves through the help of the teacher.

Research studies show that teacher strategies of instruction often hinders physics students from learning effectively (Oladejo, Olosunde, Ojebisi and Isola, 2011; Wanbugu, Chiangeiywo, and Ndirit, 2013). To this effect, physics teacher must have the good content knowledge and sound pedagogical knowledge. Otherwise, the instruction will not be effective. On this background Kim (2005) suggests that a constructivist teacher should modify their instructional strategies in the process of teaching based on students; thought, experience and or interests.

Constructivist class advocates active and interactive classroom as typically obtained in the authentic learning. Therefore, for the students to learn physics well, the teacher should encourage students' participation. A constructivist teacher needs to use cooperative teaching strategies through student interactions, respect sharing of ideas and learning tasks (Kim, 2005).

\section{Conclusion}

The paper developed a constructivist model where students learning is the center where all other learning processes revolve around. The author correlates constructivism with the authentic learning: the two being student-centered paradigm of learning. The model was applied to physics classroom for effective learning of the students. It was highlighted that for effective physics learning; physics teacher must always consider the students' prior knowledge. This prior knowledge determines everything the students 
learned and the teacher instruction. The paper equally argues that the teacher should promote student interactions and respect student ideas: being the kernel of the constructivist learning.

Recommendation

The apparent poor students' academic performance in physics due to teacher strategies of instruction requires a more result oriented method of teaching that is more of student-centered. Therefore, it is recommended that the constructivist model be fully implemented for the physics learning at all level.

\section{References}

Aina, J.K., \& Langenhoven, R. (2015). Teaching method in science education: the need for

a paradigm shift to peer instruction (PI) in Nigerian schools. International Journal of Academic Research and Reflection, 3(6), 6-15.

Aina, J.K. (2017). The physics authentic learning experience through the peer instruction. Saarbrucken: LAP Lambert Academic Publisher.

Amineh, R.J.,\& Asl, H. D. (2015). Review of Constructivism and Social Constructivism. Journal of Social Sciences, Literature and Languages1(1), 9-16. Andrews, T. (2012). What is social constructivism? Ground Theory Review, 11(1), 39-46.

Bernhard, J., Lindwall, O., Engkvist, J., \& Zhu, X. (2007). Making Physics visible and learnable through interactive lecture demonstrations. Physics Teaching in Engineering Education PTEE. Retrievedfromhttp://www.researchgate.net/publicatio n.

Biggs, J. (1999) What the student does: teaching for enhanced learning, Higher Education Research \& Development, 18(1), 57-75, DOI: 10.1080/0729436990180105.
Bredo, E. (1994). Reconstructing educational psychology: Situated cognition and Deweyian Pragmatism. Educational Psychologist,29(1), 23-25

Brooks, J. and Brooks, M. (1993).In Search of Understanding: The Case for Constructivist Classrooms, ASCD. Retrieved from http://www.sedl.org/cgi-bin/mysql/picbiboutput.cgi? searchuniqueid $=28$.

Christie, A. (2005). Constructivism and its implications for educators. Retrieved from

http://alicechristie.com/edtech/learning/constructivism /index.htm

Cornu, R.L., \& Peters, J. (2005). Towards constructivist classrooms: the role of the reflective Teacher. Journal of Educational Enquiry, 6(1), 50-64. Crouch, C.H, Watkins,J.,Fagen, A.P. \& Mazur, C. (2007). Peer Instruction: Engaging students one-onone, all at once. Research-Based Reform of University Physics. Retrieved from www.mazur.harvard.edu/sentFiles/Mazurpubs_537.pd f.

Deslauriers, L., Schelew, E., \& Wieman, C. (2011). Improved learning in a large-enrollment Physics class. Science, $\quad 332(2011), \quad$ 862-864. http://doi.org/10.1126/science.1201783 Educause Learning Initiative (2005, August). Interaction: Principles and Practice. ELI Summer Session, pp. 1-9.

Eggen, P. \& Kauchak, D. (1999). Educational psychology: Windows on classrooms (4th ed.). Prentice Hall. Eraikhuemen, L., \&Ogumogu, A .E. (2104).An assessment of secondary school Physics teachers conceptual understanding of force and motion in Edo South senatorial district. Academic Research International, 5(1), 253-262.

Fagen, A.P. (2003). Assessing and enhancing the introductory science courses in Physics and Biology: Peer Instruction, classroom demonstration, and genetic vocabulary. (Doctoral dissertation) Harvard University Cambridge, Massachusetts. 
Retrieved

http://www.researchgate.net/publication.

Folashade, A, \&Akinbobola, A.O. (2009). Constructivist problem-based learning technique and the academic achievement of Physics students with low ability level in Nigerian secondary schools. Eurasian Journal of Physics and Chemistry Education, $1(1), 45-51$.

Garbett, D. (2011). Constructivism deconstructed in science teacher education. Australian Journal of Teacher Education, 36(6), 36-49.

Hein, G. (1991). Constructivist learning theory. In The Museum and the Needs of People. CECA (International Committee of Museum Educators) Conference Jerusalem Israel (pp. 15-22). Jerusalem: Institute for Inquiry.

Herrington, J., \& Kelvin, L. (2007). Authentic learning supported by technology: 10 suggestionsandcases of integration in classrooms. Educational Media International, 44(3), 219-236.

Huang, H. (2002). Toward constructivism for adult learners inonline learning environments. British Journal of Educational Technology, 33(1), 27-37

Johnston, S., \& Cooper, J. (1997).Instructional scaffolding to improve learning. Cooperative And College Teaching, 9(3), 1-6.

Kim, B. (2001). Social constructivism. In M. Orey (Ed), Emerging perspectives on learning, teaching, and technology. Retrieved from http://www.coe.uga.edu/epltt/SocialConstructivism.ht $\mathrm{m}$.

Kim, J.S. (2005). The Effects of a Constructivist Teaching Approach on Student Academic Achievement, Self-concept, and Learning Strategies. Asia Pacific Education Review, 6(1), 7-19.
Kirschner, P A., Sweller,J.,\& Clark, R. E. (2006). Why minimal guidance during instruction does not work: An analysis of the failure of constructivist, discovery, problem-based, experiential, and inquiry-based teaching. Educational Psychologist, 41(2), 75-86, DOI: 10.1207/s15326985ep4102_1

Kroll, R.L. (2004). Constructing constructivism: how student teachers construct ideas of development, knowledge, learning, and teaching. Teachers and Teaching: theory and practice, 10(2), 200-221

Liu, C.H., \& Matthews, R. (2005). Vygotsky's philosophy: Constructivism and its criticisms examined. International Education Journal, 6(3), 386399.

McCarthy, J. P.,\& Anderson, L. (2000). Active learning techniques versus traditional teaching styles: Two experiments from history and political science. Innovative Higher Education, 24(4), 279-294. http://doi.org/10.1023/B:IHIE.0000047415.48495.05.

Mekonnen, S. (2014) Problems challenging the academic performance of Physics students in higher governmental institutions in the case of Arbaminch, Wolayita Sodo, Hawassa and Dilla Universities. Natural Science, 6,362-375.

Oladejo, M.A, Olosunde,G.R, Ojebisi,A.O\&Isola,O.M. (2011). Instructional materials and students' academic achievement in Physics: some policy implications. European Journal of Humanities and Social Sciences, 2(1), 2220-9425.

Packer, M., \& Goicoechea, J. (2000).Sociocultural and Constructivist Theories of Learning: Ontology, Not Just Epistemology. Educational Psychologist 35, 227-241.

Powell, K.C., ED.D., \& Kailna, C. J. (2009). Cognitive and social constructivism: Developing tools for an effective classroom. Education, 130(2), 241249 
Prawat, R.S., \&Floden, R.E. (1999). Philosophical

perspectives on constructivist views of Learning. Educational Psychology, 29(1), 37-48.

Rodrigues, A., \& Oliveira, M. (2008). The role of critical thinking in Physics learning. Retrieved from http://sg.ucy.ac.cy/girep2008/papers/THE\%20ROLE \%20OF\%20CRITICAL\%20THINKING.pdf

Thirteen Ed Online (2004). Constructivism as a paradigm for teaching and learning.Retrieved fromhttp://www.thirteen.org/edonline/concept 2 class/c onstructivism/index.html.

Wanbugu, P.W., Changeiywo, J.M.,\&Ndiritu, F.G. (2013). Investigations of experimental cooperative Concept mapping instructional approach on secondary school girls' achievement in Physics in Nyeri County, Kenya. Journal of Education and Practice,4(6), 120130.

Watkins, J., \& Mazur, E. (2013).Retaining students in science, technology, engineering, and mathematics (STEM) majors. Journal of College Science Teaching, 42(5), 36-40. 